\title{
Motivasjon for deltakelse i helseundersøkelser
}

\author{
Stian Antonsen \\ Institutt for sosiologi og statsvitenskap, NTNU \\ E-post: stian.antonsen@apertura.ntnu.no
}

Forfatteren ønsker å takke professor Kristen Ringdal ved Institutt for sosiologi og statsvitenskap, NTNU for kommentarer og veiledning i arbeidet med artikkelen.

\begin{abstract}
SAMMENDRAG
Artikkelen tar utgangspunkt i de siste tiårenes markerte økning i frafallet $\mathrm{i}$ helseundersøkelser, med særlig fokus på helseundersøkelsen i Nord-Trøndelag (HUNT). Foruten å gi en gjennomgang av hvilke grupper som vanligvis er underrepresenterte i helseundersøkelser, diskuterer artikkelen ulike tiltak som kan bidra til å redusere frafallet. Datamaterialet består av fem fokusgrupper. Funnene fra studien viser at den opplevde egennytten er den viktigste faktoren for beslutningen om å delta i helseundersøkelser, men at ønsket om å bidra til forskning også er svært viktig for motivasjonen til å delta. At det å bidra til forskning oppfattes som såpass viktig, bryter med den bytteteoretiske logikken som ligger til grunn for mye av den samfunnsvitenskapelige forskningen om frafallsreduksjon. Altruistiske motiver virker å spille større rolle for deltakelse i helseundersøkelser enn hva tilfellet er i andre typer undersøkelser. Funnene antyder også at ulike grupper lar seg motivere av ulike strategier. Særlig virker det å være forskjeller basert på alder og utdanningsnivå, uten at studien kan si noe konklusivt på dette området.
\end{abstract}

Antonsen S. The motivation to participate in health studies. Nor J Epidemiol 2005; 15 (1): 99-109.

\section{ENGLISH SUMMARY}

In the last few decades we have seen a quite dramatic decrease in the attendance rates of most health studies. As low attendance rates can result in biased data sets, and hence unreliable research results, the trend has been a cause for concern for health researchers. The Nord-Trøndelag Health Study (HUNT) is no exception to this development. From 1985 to 1995 , the attendance rate dropped from almost 90 percent in 1985 to just above 70 percent in 1995. When the third round of the study is scheduled in 2006, fears are that the attendance rate will drop further.

The present study analyzes the motivation to participate in the Nord-Trøndelag Health Study. It aims at improving the understanding of respondents' decision of whether to participate in the health study by identifying key motivational factors.

Data was collected through the use of focus group methodology. The focus group participants were selected strategically to have a predominance of participants from categories that were underrepresented in the 1985 and 1995 studies, notably men under the age of 30 living in the more densely populated areas of the county. Emphasis was also put on recruiting informants who were invited, but who omitted to attend the studies in 1985 and 1995.

The results show that most informants were positively minded about participating in the health study. Practical obstacles were seen as the most significant barriers to participation.

The primary motivation for participating was the perceived self-interest involved in receiving a free medical examination. The secondary motivation was to contribute to scientific research. Although agreeing that selfinterest was the primary motive, the elderly informants (over 65 years of age) as well as the highly educated ones rated the contribution to science higher than other informants. The elderly also saw participating in the health study as a form of civic duty.

While use of various kinds of incentives normally improves response rates in surveys, the informants in this study were rather sceptical of using incentives to increase the attendance rate. Many felt that the use of incentives would impose an unwanted commercial feature into the realm of health, and that this could possibly undermine the public's confidence in the study. This suggests that health studies differ from social science survey research. Health related information was seen as more private and sensitive than other types of survey information, e.g market research, and should therefore be particularly guarded against commercial interests.

Contrary to what seems to be the assumption in the survey literature, the results of the study indicate that different categories of people are motivated by different strategies of nonresponse reduction. Especially, there appears to be variations based in age and level of education. Although this study can serve as an example, such variations need to be tested quantitatively in order to determine the connection more conclusively. 


\section{INNLEDNING}

Fremmøtestatistikken er et viktig parameter for å kunne vurdere kvaliteten i enhver undersøkelse. I undersøkelser basert på frivillig deltakelse må en alltid regne med noe frafall, men i de siste tiårene har det vært en klar tendens til økning i frafallet for de fleste typer av surveyundersøkelser (Thomsen og Siring 1980; Goyder 1987; DeLeeuw og Hox 1996; Belsby 1997; Groves et al. 2002).

Denne utviklingen har også gjort seg gjeldende for helseundersøkelser. Ved den første helseundersøkelsen i Nord-Trøndelag (HUNT I) i 1985 lå frafallet på knappe 12 prosent. Ved HUNT II ti år senere var frafallsandelen nærmere 29 prosent, altså mer enn en dobling. For å kunne bremse denne utviklingen frem mot HUNT III, som etter planen skal ha oppstart i 2006, ble det besluttet å gjennomføre et forstudium for å undersøke hvilke motiver som kan ligge bak beslutningen om å delta/ikke delta i helseundersøkelsen, og hvilke tiltak som kan gjøres for å redusere frafallet. Fokusgrupper ble valgt som den mest egnede metode for datainnsamling. Denne artikkelen oppsummerer resultatene fra denne undersøkelsen.

Artikkelen er disponert som følger: Etter en gjennomgang av hvilke grupper som vanligvis er underrepresenterte i norske helseundersøkelser beskrives mulige faktorer som kan redusere frafall. Deretter beskrives resultatene fra fem fokusgrupper om motivasjon for deltakelse. Avslutningsvis identifiseres faktorer som kan bidra til å redusere frafallet $\mathrm{i}$ fremtidige helseundersøkelser.

\section{HVEM MØTER IKKE OPP VED NORSKE HELSEUNDERSØKELSER?}

En rekke internasjonale undersøkelser finner sosiodemografiske forskjeller mellom de som deltar og de som ikke deltar i helserelaterte undersøkelser. De mest vanlige forskjellene er baserte i kjønn, alder og sosioøkonomisk status (Sonne-Holm et al. 1989; Pietilä et al. 1995; Caetano 2001; Richiardi et al. 2002).

I Norge gjennomføres det større undersøkelser om helse i regi av både Statistisk Sentralbyrå (SSB) og Folkehelseinstituttet/ Statens Helseundersøkelser. En gjennomgang av disse viser at det også i Norge er en del systematiske skjevheter i frafallet.

\section{SSBs undersokelser}

Statistisk sentralbyrå har gjennomført fire intervjubaserte undersøkelser om helseforhold, i 1968, 1975, 1985 og 1995. Frafallsraten har steget jevnt og trutt: I 1968 var den på beskjedne 5,4 prosent, i 1975 var tallet 11,4, undersøkelsen i 1985 endte med 21,3, mens frafallet i 1995 var kommet opp i 24,6 prosent (Belsby og Vedø 1998; SSB 1970, 1977, 1987, 1999). I undersøkelsen fra 1968 var det en viss skjevhet $\mathrm{i}$ frafallet mellom menn og kvinner.

Aldersfordelingen i undersøkelsene fra 1968 og
1975 viser at det er aldersgruppene fra 15 til 29 år som har det høyeste frafallet. Det er særlig menn i denne alderen som har høyt frafall. I 1985 er det aldersgruppen 25-44 år som særlig faller fra, og også her er det menn som dominerer (SSB 1968, 1975).

I forbindelse med undersøkelsen i 1995 ble det gjennomført en grundig frafallsanalyse. Denne analysen skilte ut en rekke variabler som kunne bidra til å forklare frafallet i undersøkelsen. Sannsynligheten for deltakelse økte med stigende utdanning og inntekt. For alder var sammenhengen ikke-lineær. Svarandelen økte med stigende alder frem til aldersgruppen 26-40 år, da den gikk over til å synke med stigende alder. Kurven hadde med andre ord en omvendt U-form. Personer som oppga seg selv som enpersons-husholdning hadde markert lavere deltakelse enn personer som inngikk i større husholdningstyper. Personer bosatt i spredtbygde strøk hadde også høyere deltakelse enn de som bodde i tettbygd strøk. Personer som inngikk i husholdninger hvor en eller flere av medlemmene mottok sosialhjelp hadde også lavere deltakelse enn personer i husholdninger som ikke mottok sosialhjelp (SSB 1999).

Årsakene til frafall synes å ha endret seg noe for SSBs helseundersøkelser. Mens den vanligste frafallsårsaken i 1968 var at intervjuobjektene befant seg på jobb, skole eller i militærtjeneste, er det nekting som er den vanligste årsaken for alle de senere undersøkelsene.

\section{Folkehelseinstituttets undersokelser}

Mens SSBs undersøkelser er utvalgsundersøkelser, er undersøkelsene tilknyttet Folkehelseinstituttet (FHI) screeningundersøkelser som gjerne omfatter hele populasjoner. FHI er med på å administrere totalt ni helseundersøkelser. I det følgende beskrives frafallsmønstrene i de største av disse, med hovedvekt på helseundersøkelsen i Nord-Trøndelag.

\section{Helseundersokelsen i Nord-Trondelag 1984-1986 (HUNT I)}

Gjennomgangen av frafallsmønstrene ved HUNT I er basert på Holmen et al. (1989). Frafallet i den første HUNT-undersøkelsen var meget lavt. Av de 85100 personene som tilfredsstilte kriteriene for å delta var det 10123 som ikke møtte, noe som gir et frafall på 11,9 prosent (Holmen et al. 1989). Frafallsanalysen viser at gruppen "ikke møtt" skilte seg fra gruppen "møtt" ut fra kjennetegn som alder, kjønn og bosted.

Alder og kjønn. Alder og kjønn var bakgrunnsvariablene med de klareste skjevhetene. Frafallet var størst i aldersgruppene mellom 20 og 30 år, samt for aldersgruppene over 80 år.

Kvinner hadde høyere frammøte enn menn i alle aldersgrupper frem til 65 år. Forskjellene var mest uttalt $\mathrm{i}$ de yngste aldersgruppene. For kategoriene over 65 år er det menn som har det høyeste frammøtet. For alle aldersgruppene samlet hadde kvinner en fram- 
møteprosent på 89,9 , mens det tilsvarende tallet for menn var på 86,3 prosent.

Bosted. Frammøtet varierte naturlig nok noe fra kommune til kommune, men alle kommunene hadde et frammøte på 84 prosent eller høyere. Det kan synes som om frammøtet $\mathrm{i}$ bykommunene var noe lavere enn i de mindre kommunene. Både Namsos, Steinkjer, Verdal, Levanger og Stjørdal var blant kommunene med størst frafall.

\section{Helseundersøkelsen i Nord-Trondelag 1995-1997 (HUNT II)}

Informasjonen om frafallsmønstrene ved HUNT II er hentet fra HUNTs internettsider (www.hunt.ntnu.no). I den andre utgaven av HUNT var frafallet på 29,6 prosent. I grove trekk er det de samme variablene som preger frafallsmønstrene ved HUNT II som ved HUNT I.

Også i HUNT II er det de yngste og eldste aldersgruppene som har den laveste deltakelsen. Imidlertid har det skjedd oppsiktsvekkende endringer $i$ frafallet $i$ de yngste aldersgruppene. For aldersgruppen 20-29 år var oppmøtet helt nede i 49 prosent. Dette er over 20 prosentpoeng lavere enn de tilsvarende tallene fra HUNT I.

Kjønnsforskjellene i HUNT II viser også et liknende mønster som HUNT I. Menn har en gjennomgående høyere frafallsrate enn kvinner, med unntak av aldersgruppen 80-89 år, og også her er det særlig unge menn som har lav deltakelse.

Også for HUNT II er det en viss tendens til at det er utkantkommunene som har det laveste frafallet. Imidlertid er forskjellene mellom by- og utkantkommuner klart lavere enn ved HUNT I.

\section{Helseundersokelsen i Oslo (HUBRO)}

Helseundersøkelsen i Oslo ble gjennomført i 20002001 og omfattet om lag 40000 personer i utvalgte aldersgrupper mellom 30 og 76 år (Søgaard et al. 2004). Frammøtet i denne undersøkelsen var på 46 prosent, noe som må sies å være svært lavt. Frafall var særlig knyttet opp mot kjennemerkene kjønn, alder, utdanning og fødeland.

Kjønn og alder. Kvinner hadde i gjennomsnitt et høyere frammøte enn menn. Alt i alt var frammøtet 49 prosent for kvinner og 42 prosent for menn (Kværnsveen 2002). De yngste hadde det laveste frammøtet (36 prosent), mens de middelaldrende hadde det høyeste (55 prosent).

Utdanning. Personer med universitets- eller høyskoleutdanning var noe overrepresenterte i HUBROutvalget sammenlignet med populasjonen. Andelen med høyere utdanning er om lag fire prosentpoeng høyere i utvalget enn i populasjonen (Søgaard et al. 2004). Denne tendensen gjelder for begge kjønn, alle aldersgrupper og ulike regioner i Oslo.

Fødeland. Det er visse ulikheter i fremmøtet for personer født i Norge, og personer født i andre land. For personer født i Norge var frammøtet på 46 prosent. Blant innvandrere fra vestlige land var det 42 prosent som deltok, mens personer født i ikke-vestlige land hadde et oppmøte på 39 prosent (Søgaard et al. 2004). Det er uklart hva dette mønsteret skyldes, men språkproblemer kan tenkes å være en av årsakene.

\section{Andre helseundersokelser}

Det finnes en rekke helseundersøkelser i tillegg til de som har blitt nevnt ovenfor. En gjennomgang av noen av disse undersøkelsene viser at frafallet følger mye av de samme mønstrene i alle undersøkelsene. Ved helseundersøkelsene i Oppland/Hedmark, Hordaland, Tromsø og Finnmark er det gjennomgående at menn deltar mindre enn kvinner (www.fhi.no). Samtidig er frafallet høyest i de yngste og eldste aldersgruppene. Det virker å være få norske helseundersøkelser som gjør grundigere analyser av frafallet. Eventuelle skjevheter basert på sosioøkonomiske bakgrunnsvariabler blir sjelden gjort gjenstand for nærmere analyse. En studie av Jacobsen og Thelle (1988) er et unntak her. I tillegg til skjevheter basert på kjønn og alder, finner de også at ugifte, røykere og personer i stillesittende yrkestyper var underrepresenterte i helseundersøkelsen i Tromsø.

Det som skiller helseundersøkelsene mest fra hverandre er det totale oppmøtet. Helseundersøkelsen i Nord-Trøndelag skiller seg ut med oppmøte på $90 \mathrm{og}$ 70 prosent, noe som må sies å være meget høyt for en totalpopulasjonsstudie.

\section{FAKTORER SOM KAN REDUSERE FRAFALLET I HELSEUNDERSØKELSER}

Den samfunnsvitenskapelige metodelitteraturen omtaler en rekke strategier som kan brukes for å minimere frafallet i surveyundersøkelser. De ulike strategiene kan grovt sett grupperes i tre kategorier: For det første er det snakk om strategier som søker å øke egennytten av å delta i undersøkelsen. For det andre kan egenskaper ved selve undersøkelsen manipuleres til å fremstå mest mulig tiltalende for deltakerne. For det tredje vil også personlige holdninger være et viktig premiss $i$ beslutningen om å delta/ikke delta i undersøkelsen, noe som også får konsekvenser for hvordan en søker å motivere til deltakelse. Strategiene innenfor disse tre kategoriene er relativt godt utprøvde på generelle spørreundersøkelser. Hvordan slike strategier kan anvendes $\mathrm{i}$ forhold til helseundersøkelser finnes det imidlertid lite systematisk forskning på. Dette er et viktig spørsmål for fremtidige helseundersøkelser og vil derfor bli viet særlig oppmerksomhet i det videre. En kort gjennomgang av hva som ligger i de ulike strategiene er derfor nødvendig.

\section{Deltakernes egennytte}

Beslutningen om å delta eller ikke delta i en undersøkelse, ses ofte som et regnestykke over gevinster og kostnader (Dillman 2000). Ulike former for incentiver er en strategi som tar sikte på å forbedre gevinstsiden av dette regnestykket. I stedet for å kun be om velvilje 
er man altså innstilt på å gi respondentene noe tilbake for sin deltakelse. Særlig i USA har det blitt mer og mer vanlig at respondentene mottar en mindre pengesum, en eller annen form for gave, eller inngår i en trekning av en premie i "bytte" mot at de deltar i undersøkelsen. Incentivene kan enten gis til alle som får forespørsel om å delta i undersøkelsen, eller være forbeholdt de som velger å delta i undersøkelsen.

Uavhengig av hvilke typer av incentiver det er snakk om, finner de aller fleste undersøkelser en klar positiv effekt av incentiver (Watruba 1966; Armstrong 1975; Fox et al. 1988; Church 1993; Edwards et al. 2002).

Bruk av incentiver virker å være noe sjeldnere i undersøkelser om helse enn hva tilfellet er i andre typer surveyundersøkelser. Det er gjort noen studier som analyserer effekten av incentiver i surveyundersøkelser om helse (dvs. ikke brede screeningundersøkelser). Disse rapporterer stort sett om positiv effekt, selv om funnene ikke er konsistente. Kalantar og Talley (1999) oppnådde en økning i svarprosenten på sju prosentpoeng ved å gi respondentene deltakelse $\mathrm{i}$ et lotteri. Perneger et al. (1993) oppnådde en økning på ni prosentpoeng ved å gi tilby ca. 50 kroner til de som valgte å delta i undersøkelsen, mens Tjerbo et al. (2005) oppnådde 5 prosentpoengs økning ved å gi et flaxlodd til alle som ble invitert til å delta. Asch et al. (1997) finner derimot ingen effekt av incentiver.

\section{Egenskaper ved undersokelsen}

Mens bruken av incentiver retter seg mot å øke deltakernes gevinster ved å delta i undersøkelsen, er designet av undersøkelsen mye et spørsmål om å redusere respondentenes "kostnader" i form av tid, oppmerksomhet, innsats etc. Det finnes en mengde sammenligninger av forskjellige teknikker og prosedyrer for å gjøre undersøkelsen best mulig for respondentene. Funnene er langt fra konsistente, men noen teknikker har etter hvert blitt relativt godt underbygde:

1) Forhåndsvarsel. Flere studier konkluderer med at frafallet kan reduseres gjennom å sende ut et forhåndsvarsel om at undersøkelsen er på vei (Linsky 1975; Harvey 1987; Fox et al. 1988). Bruk av forhåndsvarsel gjør respondenten oppmerksom på at han eller hun snart vil motta en undersøkelse. Forhåndsvarsler antas å minske faren for at undersøkelsen forveksles med reklame eller andre former for "uønsket" post. Ved HUBRO-undersøkelsen ble det imidlertid gjort et randomisert forsøk med en to-trinns invitasjon uten at dette gav noen økning i fremmøtet (Søgaard og Selmer 2005).

2) Invitasjon/informasjonsmateriell. Et av hovedmålene med informasjonsmateriellet er å gjøre undersøkelsen interessant for respondentene. En rekke studier peker ut deltakernes interesse for tema som en av de viktigste predikatorene for deltagelse (Heberlein og Baumgartner 1978). I en undersøkelse av Goyder (1987) oppga over halvparten av de spurte at et inte- ressant tema var "ekstremt viktig" eller "veldig viktig" for deres beslutning om å delta i en undersøkelse. $\AA$ forsøke å stimulere respondentenes interesse for temaet kan muligens også antas å forbedre kvaliteten på datamaterialet (færre som fyller ut skjemaet på "måfå").

3) Lengde og layout på spørreskjema. Det virker naturlig å anta at lengden på et spørreskjema har innvirkning på hvor mange som tar seg bryet med å fylle ut skjemaet. Like fullt er ikke dette forholdet så entydig som en kanskje skulle tro. Mens noen finner at korte skjema har lavere frafall enn lengre (Kalantar og Talley 1999), finner andre igjen at det ikke er sammenheng mellom skjemalengde og frafall (Lund og Gram 1998).

Det har også blitt gjort eksperimenter som indikerer at tittelen på spørreskjemaet er viktig: Lange titler som inneholder faguttrykk kan gi vesentlig dårligere svarprosent enn korte og "folkelige" titler (ibid).

4) Påminnelser/purringer. Sammen med incentiver, er gjentatte påminnelser den strategien som har bredest empirisk støtte. Dillman (2000) anslår at å anvende en eller flere påminnelser øker svarprosenten med mellom 20 og 40 prosent. Basert på materiale fra HUBROundersøkelsen, fant Selmer et al. (2003) en økning på 16 prosentpoeng ved å anvende to påminnelser. Påminnelser sikter på å redusere den delen av frafallet som skyldes forglemmelser og andre praktiske årsaker.

\section{Deltakernes holdninger}

Deltakernes holdninger antas å spille en viktig rolle for beslutningen om å delta/ikke delta i undersøkelser (Stinchcombe et al. 1982; Brennan og Hoek 1992).

1) Tillit til arrangør. Stinchcombe et al. (1981) fremhever viktigheten av at respondentene har tillit til institusjonen eller bedriften som arrangerer undersøkelsen. Særlig viktig er det at respondentene føler seg helt trygge på at all informasjon som samles inn vil bli behandlet konfidensielt. Svært mange studier finner også en sammenheng mellom hvem som foretar undersøkelsen, og svarprosenten i undersøkelsen: Offentlige eller universitetsbaserte undersøkelser scorer gjennomgående bedre enn privatfinansierte undersøkelser (Heberlein og Baumgartner 1978; Fox et al. 1988; Edwards et al. 2002). Dette kan ha en sammenheng med respondentenes tillit til konfidensialitet, men denne koblingen er ikke videre undersøkt i litteraturen.

2) Holdninger i forhold til privatliv. Goyder og Leiper (1985) stiller spørsmål ved om økningen i frafall i surveyundersøkelser kan skyldes at folk i større grad verner om sine privatliv, og at ulike former for surveyundersøkelser oppfattes som en invasjon av privatlivet. Dette støttes blant annet av DeMaio (1980).

3) Altruistiske motiver. En rekke studier finner at undersøkelsens samfunnsmessige nytte er viktig for motivasjonen for deltakelse. Et eksempel her er Goyder (1987), som fant at over 40 prosent oppga den sosiale nytten av undersøkelsen som "ekstremt viktig" 
eller "veldig viktig" for beslutningen om å delta i undersøkelsen.

Når statlige og universitetsbaserte undersøkelser jevnt over oppnår bedre svarandel kan det ha sammenheng med dette forholdet. Det kan tenkes at slike institusjoner har en høyere grad av autoritet som gjør at en appell til å hjelpe andre oppfattes som mer legitim enn tilfellet er i forhold til markedsundersøkelser eller andre former for kommersielle undersøkelser.

\section{Oppsummering}

Frafallsanalyser av norske helseundersøkelser viser gjennomgående sammenhenger mellom frafall og bakgrunnsvariablene kjønn og alder. Det er særlig yngre menn som er underrepresenterte. Samtidig vet vi lite om hva som ligger til grunn for disse skjevhetene, ettersom det har blitt gjort få forsøk på å undersøke hvilke motiver som ligger bak beslutningen om å delta i undersøkelser eller ikke.

Surveylitteraturen beskriver flere mulige tiltak for å redusere frafallet. Mye av forskningen på feltet stammer imidlertid fra USA, og hvor overførbart dette er til andre kontekster er et uavklart forhold. Ettersom det er kulturelle forskjeller mellom Norge og USA, er det ikke gitt at funnene fra amerikansk forskning er direkte overførbare til norske forhold. Det kan tenkes at nordmenn har andre motiver for å delta i undersøkelser enn det amerikanere og andre har.

Dette vil være svært viktige spørsmål for å kunne forstå mer om frafallsproblemet i helseundersøkelser og hvordan en kan jobbe for å redusere frafallet i fremtidige undersøkelser.

\section{DAtAGRUNNLAG}

Totalt ble det gjennomført fem fokusgrupper med mellom tre og ni deltakere. Totalt deltok 28 personer i undersøkelsen. Utvelgelsen av informanter ble gjort på flere måter:

1. "Snøballmetoden". En deltaker foreslår nye deltakere i sin bekjentskapskrets.

2. Rekruttering via bedriftshelsetjeneste.

3. Rekruttering via HUNTs innkallingsfil.

Deltakerne ble valgt ut på bakgrunn av bosted, kjønn og alder. Det ble ikke gjort noen forsøk på å skape noen form for representativitet $\mathrm{i}$ datamaterialet, noe som uansett ville vært umulig på grunn av utvalgets størrelse. I stedet ble det lagt vekt på å få flest mulig deltakere i de kategoriene som vanligvis er underrepresenterte i helseundersøkelser. Det vil si at datamaterialet har en overvekt av menn under 30 år. Det ble også lagt vekt på å få med personer som ikke deltok på HUNT II. Tabell 1 gir en oversikt over datamaterialets sammensetning ut fra de nevnte egenskapene.

Når en skal undersøke forhold som har med frafall og motivasjon å gjøre møter en visse metodologiske problemer: Det er relativt sannsynlig at de som ikke møter opp til helseundersøkelsen heller ikke er spesielt motiverte for å delta i fokusgruppene. Dette innebærer at informasjonen fra fokusgruppene muligens er preget av at deltakerne i utgangspunktet er motiverte for helseundersøkelsen.

Denne faren har blitt forsøkt kompensert gjennom å benytte flere metoder i rekrutteringen av deltakere. For eksempel innebærer "snøballmetoden" at forespørselen om å delta kommer fra noen en kjenner. Dette kan ha bidratt til å dra med noen som ellers ville ha takket nei. For de deltakerne som ble rekruttert via HUNTs innkallingsfil ble det i tillegg sendt ut flere invitasjoner til personer som ikke deltok i HUNT II, enn til personer som deltok.

Uansett om fokusgruppene skulle være overrepresenterte av personer som i utgangspunktet er motiverte for å delta i helseundersøkelsen, betyr ikke det at den informasjonen som kommer frem i gruppene ikke er interessant. Å beholde de deltakerne en allerede har er minst like viktig som å "omvende" de som ikke er motiverte. Eventuelle skjevheter i datamaterialet anses derfor ikke å utgjøre noe vesentlig problem for undersøkelsen.

\section{RESUltater}

\section{Motivasjon for deltakelse}

Informantene oppga hovedsakelig to hovedmotiver for å delta: Egennytte og bidrag til forskning. Når disse to motivene skiller seg ut, er dette konsistent med undersøkelser gjort i forbindelse med HUBRO (Kværnsveen 2002).

På spørsmål om hvorfor det var interessant å være med på HUNT, virket de fleste å være enige om at gratis eller billig helsesjekk er et viktig motiv for å delta $i$ HUNT. Samtidig var det en del forskjeller i hvordan gruppene diskuterte rundt denne prioriteringen. Særlig var det forskjeller mellom de ulike aldersgruppene.

De to gruppene som besto hovedsakelig av yngre menn med lav utdannelse ("unge menn" og "industriarbeiderne"), trakk frem egennytten som det eneste motivet for deltakelse:

"Jeg tenker ikke $i$ det hele tatt på det [forskning], jeg tenker kun på meg selv når det gjelder noe sånt som en helseundersøkelse. Det er for mitt eget beste at jeg går dit."

Tabell 1. Oversikt over deltakere i undersøkelsen, aldersgruppe og deltakelse ved HUNT II.

\begin{tabular}{lccc}
\hline Gruppe & Aldersgruppe & Deltatt & Ikke deltatt \\
\hline "Unge menn" & Under 30 & 2 & 1 \\
"Studentene" & Under 31 & 2 & $3^{*}$ \\
"Industriarbeiderne" & $19-30$ & 2 & $7^{* *}$ \\
"De middelaldrende" & $50-60$ & 5 & 3 \\
"De eldre" & over 65 & 3 & 0 \\
\hline
\end{tabular}

* Studenter med folkeregistrert adresse i Nord-Trøndelag

** Disse deltakerne var for unge til å delta i HUNT II i 1995 
Det virket til å begynne med å være bred enighet om at det kun er egennytten som er motivasjonen for deltakelse. Dette skiftet imidlertid noe underveis i diskusjonen. På spørsmål om hvordan de så på det at HUNT er en stor og anerkjent helseundersøkelse, var det flere av de som i utgangspunktet kun vektla egennytten som i større grad snakket positivt om verdien av forskningen. Dette antyder for det første at denne gruppen har liten kjennskap til den forskningsmessige nytten av helseundersøkelser. Det indikerer imidlertid også at de ser den forskningsmessige nytten når de først blir gjort oppmerksomme på den. Det er også verdt å merke seg at det virker å være koblingen til "lokal stolthet" som gjør at den forskningsmessige nytten i større grad blir sett på som viktig blant disse informantene.

For studentene var dette forholdet noe annerledes. Selv om egennytten var viktig, ble det å bidra til forskning sett som det viktigste motivet for å delta. På spørsmål om hvorfor de så bidrag til forskning som så viktig, ble det blant annet trukket frem at de gjennom studiene kanskje får et nærmere forhold til forskning enn hva de ellers ville hatt, og at dette gir dem en større forståelse for verdien av forskning. En av informantene mente også at utdannelsen kanskje gjorde dem til mer bevisste i forhold til sin egen helse.

For de middelaldrende var det helsesjekken som ble beskrevet som hovedmotivet for å delta, men de så bidraget til forskning som en form for positiv bonus som hadde innvirkning på valget om å delta eller ikke.

Også denne gruppen uttrykte en viss stolthet over at HUNT er noe som Nord-Trøndelag har, som ikke finnes i samme skala $i$ andre fylker. Flere tok til uttrykk for at flere bør bli klar over at undersøkelsen er relativt spesiell:

Dette er jo noe som folk må få vite, at det er litt unikt og sånn, for det liker jo folk (...) Det kan jo vore en måte å vinkle det hele litt mer positivt, sånn at det ikke bare blir fokus på sykdom"

Også blant de eldre var det helsesjekken som ble beskrevet som det viktigste motivet for å delta i undersøkelsen:

’Jeg synes det er så greit å bli innkalt, da slipper en å tenke på det selv (...) Da får en vite det tidlig dersom det skulle vare noe $i$ veien"

Samtidig så de bidrag til forskning som positivt, selv om det ikke var hovedgrunnen for å delta. Denne gruppen skiller seg imidlertid noe fra de andre, ved at de $\mathrm{i}$ større grad så deltakelse i HUNT som en form for plikt.

"Jeg synes strengt tatt at alle bør møte opp på dette, uansett hva temaet for undersøkelsen er."

De eldre informantene beskrev generelt helseunders $\varnothing$ kelsen i svært positive ordelag, og virket å se det som en form for "dugnad" som en er med på av hensyn til fellesskapet. Her må det imidlertid understrekes at alle informantene i denne gruppen hadde deltatt i HUNT tidligere, og at diskusjonen i gruppa muligens var preget av dette.

\section{Incentiver og kostnader}

Når det gjaldt bruk av incentiver for å motivere til deltakelse, var det klare forskjeller mellom gruppene. Industriarbeiderne var svært positive til bruk av incentiver. De nevnte trekning av gavekort eller sydenreiser som mulige incentiver, og mente dette ville bidratt til å motivere dem for deltakelse.

I gruppen for de middelaldrende var det flere som mente at incentiver var det som skulle til for å få "nølerne" til å møte opp, mens andre så helsesjekken som tilstrekkelig incentiv, og at de som ikke er interesserte i helsesjekken ikke møter opp uansett.

Gruppen bestående av yngre menn var relativt lunkne $\mathrm{i}$ forhold til bruk av incentiver i helseundersøkelser. En uttalte også at han trodde det ville virke mot sin hensikt:

"Nei, hvis en begynner å blande penger inn i dette, da tror jeg ikke jeg ville kommet, synes ikke en skal begynne å betale folk for å komme, det virker litt sånn smålig."

Selv om det ikke var enighet i gruppen, virket også de eldste informantene noe skeptiske til incentiver:

"Nei, det kan vel kanskje lokke noen til à vare med, men det burde strengt tatt ikke vare nødvendig" (...) Det kan jo vare et tveegget sverd det der, det kan jo vare noen som tenker at 'det der er ikke seriøst'."

Også her ser vi noe av den "dugnadstankegangen" blant de eldre informantene. Informanten understreker også at bruk av incentiver kan slå negativt ut ved at det kan gi undersøkelsen et useriøst eller kommersielt preg.

Det ble også stilt spørsmål om hvordan det ville bli oppfattet med en eventuell egenandel for å delta $i$ undersøkelsen. De fleste gruppene var relativt delte på dette. De fleste mente at undersøkelsen i utgangspunktet burde være gratis, og at en eventuell egenandel i så fall burde være meget lav. En av informantene i studentgruppen mente at noe av trekkplasteret ved undersøkelsen forsvinner med en eventuell egenandel:

"Hvis det skal vare egenandel, da kan en jo like godt bestille en vanlig legetime. Det skal i så fall vore en ganske god oppfølging av meg personlig dersom jeg skal betale en egenandel."

En annen fra samme gruppe uttrykker imidlertid det motsatte:

"Nei, jeg synes det er greit. Når du betaler så signaliserer du på en måte at du får noe tilbake også. Hvis $d u$ betaler femti kroner så har du på en måte en liten forsikring $i$ at det blir gjort ordentlig, og at du har litt à si du også."

Når det er så vidt uklare og motstridende svar angående incentiver og kostnader, antyder det at helseundersøkelser skiller seg en del fra andre typer undersøkelser. Det kan synes som om følelsen av å "få betalt" for delta ikke passer like godt for helseundersøkelser som for vanlige surveyundersøkelser. 


\section{Arsaker til frafall}

På spørsmål om hva som kan få folk til å ikke delta i helseundersøkelsen, var det stort sett enighet om at det primært er praktiske forhold som hindrer folk fra å delta. Her trekkes det frem forhold som vanskeligheter med å ta fri fra jobb, tapt lønn for den tiden en bruker på HUNT, problemer med å komme seg til stasjonene, samt rene forglemmelser.

Unntaket var her industriarbeiderne som i tillegg til disse faktorene også mente at holdninger spiller inn:

'Jeg tror nok de fleste har anledning, men det å møte opp på sånne ting, det er ikke spesielt viktig for meg. Tror det er mange som rett og slett ikke gidder."

Dette gjøres særlig gjeldende overfor yngre mennesker, som føler seg friske og av den grunn ikke ser den samme egennytten i å delta i helseundersøkelser.

\section{Om undersokelsen}

\section{Tema}

Et av spørsmålene som deltakerne ble bedt om å diskutere, var hvilke helsemessige tema de var mest opptatte av. På dette området var det særlig to tema som gikk igjen i de ulike gruppene:

1. Kreft. Samtlige grupper nevner kreft som en av de viktigste tingene de ønsker å bli undersøkt for. Kvinnene nevner her brystkreft som det mest interessante, særlig i forhold til yngre kvinner som ikke får automatisk tilbud om mammografi. Også føflekkreft blir nevnt som et viktig tema.

2. Livsstilsrelaterte sykdommer. Alle gruppene var inne på forhold som blodtrykk, kolesterolnivå og diabetes. Blant de $\mathrm{i}$ aldersgruppen 50-60 år ble dette særlig sett i forhold til hjerte-/ karsykdommer.

De fleste deltakerne, uavhengig av alder, vektla at de ønsket størst mulig valgfrihet og fleksibilitet $i$ forhold til helsesjekken. Særlig ses det som positivt dersom en kan velge mellom undersøkelser for arvelige sykdommer som astma, MS og benskjørhet. Disse undersøkelsene ble først og fremst sett som mulige tillegg til en felles, obligatorisk undersøkelse.

Gruppen bestående av studenter så det som positivt dersom helsesjekken hadde rom for å stille helserelaterte spørsmål som ikke nødvendigvis var en del av selve undersøkelsen:

"Det hadde vart greit om en kunne stille spørsmål til legen. Det kan vare småting en ønsker svar på, men som en ikke gidder å oppsøke fastlegen for."

Det var ingen store forskjeller mellom gruppene når det gjelder hva de ønsket å få svar på om egen helse. Den mest synlige forskjellen var at de yngre deltakerne virket å være noe mer opptatte av kreft enn andre sykdommer, mens de middelaldrende i større grad diskuterte hjerte-/karsykdommer. For begge disse gruppene var det primære ønsket til helsesjekken muligheten for å bli undersøkt for sykdommer som en kan ha uten å være klar over det selv. En av de yngre informantene oppsummerer dette slik:
"Det er jo mange sykdommer en ikke ser, som en kan ha lenge uten å vite det. Så da kan jo denne helsesjekken vare en mulighet til å oppdage det."

På spørsmål om det var ønskelig med ett definert hovedtema for undersøkelsen stilte informantene seg derfor stort sett likegyldige. Den opplevde egennytten ser dermed ut til å være en større motivasjonsfaktor enn at undersøkelsen har et tema som interesserer.

\section{Spørreskjema}

Samtlige informanter oppga at de ønsket å enten fylle ut spørreskjemaet før de kommer til stasjonene, eller fylle ut skjemaet før eller rett etter helsesjekken. Dette for å bli ferdige med alt på en gang, samtidig som det minsker faren for at en glemmer å levere spørreskjemaet.

Det var også flere som understreket viktigheten av at det finnes personale på stasjonene som kan bistå $\mathrm{i}$ utfyllingen av spørreskjemaet, siden eldre, svaksynte, dyslektikere med flere, vil kunne ha vanskeligheter med å fylle ut skjemaet. Herunder uttrykkes det også ønske om at en i visse tilfeller kan besvare skjemaet muntlig i form av et surveyintervju.

Blant industriarbeiderne var det flere som mente det var viktig at innkalling og eventuelt spørreskjema ikke ble sendt ut for lang tid i forveien, dette for å hindre at det går i glemmeboken. Hvis innkallingen kommer lang tid i forveien er det i så fall ønskelig med en påminnelse kort tid før timen. Her nevnes det et kreativt forslag om å foreta purringer per SMS for å unngå at purringer forveksles med reklamepost. Den eneste formen for purring/påminnelse som oppfattes negativt, er telefonoppringinger. Også de andre gruppene er negative til eventuelle påminnelser per telefon.

Også lengden på spørreskjemaet ble beskrevet som viktig av industriarbeiderne. De var klare på at de sjelden fylte ut spørreskjema som var lange og tidkrevende. Også de middelaldrende mente det var viktig å holde lengden på spørreskjemaet nede.

Det ble også spurt om det var ønskelig med mulighet for å besvare spørreskjemaet elektronisk. Holdningen til dette var relativt lunken, selv om de fleste vektla at det er positivt med mest mulig fleksibilitet $i$ undersøkelsen. De fleste virket å foretrekke papirform, selv om noen av de yngre deltakerne så en viss verdi $\mathrm{i}$ å kunne levere spørreskjemaet elektronisk. Det å kunne fylle ut skjemaet elektronisk ble imidlertid ikke oppfattet som noen motiverende faktor i seg selv.

\section{Tidsbruk}

Når det gjelder hva som ble oppfattet som akseptabel tidsbruk, var det forskjeller mellom gruppene. Generelt virket aksepten for å bruke tid på undersøkelsen å stige i takt med stigende alder. De yngste var med andre ord de som ønsket å bruke minst tid på undersøkelsen. Her var det flere som mente at en halvtime var den øvre grensen, selv om det ikke alle var enige i dette. Blant de andre gruppene ble grensene for akseptabel tidsbruk plassert rundt en til en og en halv time, bortsett fra de eldste deltakerne som alle var pensjonister. Denne 
gruppen så ikke noen spesielle begrensninger når det gjelder tidsbruk.

Her ble det også stilt spørsmål om det var ønskelig å dele undersøkelsen opp i to faser for å unngå kødannelser på stasjonene. Samtlige informanter var mot dette, og begrunner det med at en da må gjøre samme "tiltaket" to ganger.

\section{Plassering av stasjoner}

Flertallet av informantene ønsket at stasjonene ble plassert $\mathrm{i}$ tettstedene, ettersom det er der flertallet av arbeidsplasser befinner seg. Imidlertid var det bred enighet om at det er ønskelig med mobile enheter. Særlig informantene fra mer grisgrendte strøk mente det var mange som kunne ha vanskeligheter med å komme seg inn til tettstedene, og at det derfor ville hjelpe med mer mobile stasjoner.

Industriarbeiderne var særlig positive til mobile enheter dersom disse også kan stoppe ved de største arbeidsplassene i fylket. Disse informantene så sin arbeidssituasjon som et av de største hindrene for deltakelse, grunnet liten fleksibilitet $\mathrm{i}$ forhold til arbeidstid og arbeidsoppgaver. Det viktigste tiltaket for å få med industriarbeidere, mente de ville være å "spille på lag" med arbeidsgiverne:

"Får du fri med lønn fra arbeidsgiver for å gå, da går de fleste, det tror jeg altså. Det tror jeg arbeidsgiverne vil vare interesserte $i$ også, alle er vel interesserte $i$ a ha friske ansatte? (...) Jeg hadde ikke vart her [fokusgruppen], for eksempel hvis jeg ikke hadde kunnet ta det $i$ arbeidstida."

De mente også at det ville være vanskelig for arbeidsgiverne å si nei, ettersom de fleste industribedrifter fokuserer sterkt på HMS. Mange arbeidsplasser er også knyttet til avtalen om "Inkluderende Arbeidsliv" som fokuserer mye på helse og sykefravær. Det foreslås også å lage en form for konkurranse mellom arbeidsgiverne, hvor en premierer de arbeidsgiverne med den høyeste deltakelsen.

I tillegg var det mange, særlig av de yngre, som så det som viktig at stasjonene har åpent noen kvelder og eventuelt noen helgedager.

\section{Konfidensialitet og tillit}

De aller fleste informantene oppgir å stole fullt og helt på konfidensialiteten rundt helseundersøkelsen, selv om de ser faren dersom informasjonen skulle havne $\mathrm{i}$ feil hender. En av de middelaldrende oppsummerer dette slik:

"Det er ikke noe jeg tenker så mye på, men det er klart, den dagen det skjer en glipp i forhold til innsyn, da blir det vanskelig å fortsette med HUNT. Da er tilliten borte."

I diskusjonen i denne gruppen kom det frem at det var betydelig forvirring omkring anonymiseringen av spørreskjema og biologisk materiale, med tanke på om de var merket med navn eller kun nummer. Det ble uttrykt ønske om å få vite mer om prosedyrene rundt dette før neste runde av HUNT.
I gruppen for yngre menn hersket det noe usikkerhet $\mathrm{i}$ forbindelse med medieoppslag $\mathrm{i}$ etterkant av HUNT II. Noen av deltakerne mente å ha hørt at datamaterialet var blitt solgt videre til personer eller institusjoner utenfor HUNT, og uttrykte en viss bekymring rundt dette:

"Det kan jo vare et problem det der. Vi må kunne fole oss helt sikre på at dette ikke er noe som kan bli brukt mot deg på noen måte."

Like fullt virker ikke konfidensialitet å være blant de mest sentrale faktorene for beslutningen om å delta $\mathrm{i}$ undersøkelsen eller ikke.

Gruppen ble også bedt om å diskutere hvor grensen går for sensitive spørsmål, det vil si hva som oppfattes som greit å svare på i forbindelse med undersøkelsen. Her virket de yngre informantene å være noe mer tilbakeholdne enn de andre. Spørsmål som går på seksuell legning, selvmordstanker eller lignende oppfattes å være i grenseland for hva som er akseptabelt, særlig hvis legen som foretar helsesjekken skulle ha skjemaet tilgjengelig under selve undersøkelsen.

De middelaldrende og eldre oppga ingen særskilte problemer med å besvare denne typen eller andre mer sensitive spørsmål. Dette kobles opp mot tilliten til undersøkelsens konfidensialitet: så lenge de kan føle seg trygge på at informasjonen ikke kommer på avveie, er det ingenting $\mathrm{i}$ veien for å svare på mer intime og personlige spørsmål.

\section{Tilbakemeldinger på resultater}

Alle informantene ønsket tilbakemelding på resultatene av helsesjekken, uansett om det er avdekket noen sykdommer eller ikke. De fleste er positive til en avkrysningsmulighet for de som ikke ønsker tilbakemelding, men tror ikke det er mange som deltar uten å ønske tilbakemelding. Ikke uventet er det et gjennomgående ønske at tilbakemeldingen skjer så raskt som mulig.

Det er også bred enighet om at det er positivt hvis resultatene oversendes fastlegen i tillegg til en individuell tilbakemelding. Spesielt i de tilfellene hvor det avdekkes sykdommer er det viktig at fastlegen kobles tidlig inn.

\section{DisKUSJON}

Mange av de frafallsreduserende strategiene søker å minske den delen av frafallet som skyldes forglemmelser eller andre praktiske forhold. Praktiske årsaker ble også trukket frem av informantene i denne studien. Vi kan derfor anta at tiltak som forhåndsvarsel og purringer har like stor effekt $\mathrm{i}$ helseundersøkelser som $\mathrm{i}$ andre former for undersøkelser. På andre områder kan det imidlertid det se ut som om sammenhengene er noe mer kompliserte enn det mye av litteraturen legger til grunn.

Særlig gjelder dette antagelsen om at beslutningen om å delta følger en økonomisk rasjonalitet hvor 
respondentene veier kostnader opp mot gevinster, slik særlig Dillman (2000) argumenterer for. Denne antagelsen ligger til grunn for svært mye av litteraturen. Informantene i denne studien er riktignok opptatte av den egennytten som ligger i helsesjekken, men dette er ikke det eneste motivet. Det å bidra til forskning beskrives av mange som både viktig og nyttig, og noen setter til og med denne mer altruistiske faktoren som det viktigste motivet for å delta.

Dette viser seg også i informantenes holdninger overfor bruk av incentiver. Mens ulike former for incentiver brukes med hell innenfor samfunnsvitenskapelige surveyer (Haraldsen 1997), var det delte oppfatninger blant informantene $\mathrm{i}$ denne undersøkelsen. Bortsett fra industriarbeiderne, var det i alle gruppene en viss skepsis til å "belønne" folk for å delta i undersøkelsen. Dette har nok sammenheng med at informasjon om egen helse er mer personlig informasjon enn den formen for informasjon en oppgir i for eksempel markedsundersøkelser, og at de ikke oppgir denne informasjonen til hvem som helst.

En rekke studier har for eksempel vist at offentlig finansierte undersøkelser jevnt over oppnår bedre svarandel enn private (Heberlein og Baumgartner 1978; Fox et al. 1988; Edwards et al. 2002). Dette har nok noe å gjøre med tilliten til at arrangøren ikke misbruker den informasjonen en gir fra seg. Offentlige arrangører av undersøkelser vil som oftest ha rent forskningsmessig interesse $\mathrm{i}$ resultatene, mens private undersøkelser gjerne har et motiv om å bruke resultatene til å tjene penger, noe som kan få mange til å bli utrygge på hva informasjonen skal brukes til.

Dette kan også ses i lys av Goyder og Leipers (1985) tese om at vern av privatliv er en sentral faktor for beslutningen om å delta/ikke delta. Der tilliten til arrangøren er høy, vil nok terskelen for hvor privat informasjon en er villig til å gi fra seg være høy, mens en i større grad verner om denne informasjonen hvis tilliten er lav.

Skepsisen til bruk av incentiver kan slik ses i sammenheng med skillet mellom kommersielt vs. ikkekommersielt, og at følelsen av at noen "kjøper" personlig informasjon bidrar til å svekke bildet av helseundersøkelsen som "ren" forskning.

Det kan ut fra dette se ut som om holdninger til incentiver også henger sammen med graden av sensitivitet $\mathrm{i}$ undersøkelsen og respondentenes tillit til arrangøren av undersøkelsen. Tillit til institusjonen som arrangerer undersøkelsen synes å være særlig viktig i helseundersøkelser. Når det gjelder bruk av incentiver ser det altså ut til at helseundersøkelser skiller seg klart fra andre typer undersøkelser ved at bruk av incentiver vil kunne medføre svekket tillit til undersøkelsens seriøsitet, og dermed virke mot sin hensikt.

Det er også svært interessant at det her kan se ut som om det er forskjeller ut fra utdanning og alder. Selv om dette datamaterialet ikke gir grunnlag for å trekke noen former for generelle slutninger, var det relativt tydelige forskjeller mellom studentene og industriarbeiderne $\mathrm{i}$ hvordan de avveide egennytte mot altruistiske motiver. Mens studentene var mest opptatte av å bidra til det de oppfattet som interessant forskning, var industriarbeidernes første respons på dette spørsmålet at å bidra til forskning ikke var viktig i det hele tatt.

Det kan tenkes flere forskjellig forklaringer på disse forskjellene. De kan på den ene siden bunne i at høyt utdannede har et høyere kunnskapsnivå som gjør dem bedre i stand til å se nytten av forskning. En annen mulig forklaring er at høyt utdannede tilegner seg verdier som setter forskning og teoretisk kunnskap høyt. Uansett hva forskjellene kan skyldes, vil de innebære at en må ta i bruk ulike argumenter for å motivere de ulike gruppene.

Det ser også ut til å være forskjeller mellom aldersgruppene i undersøkelsene. De eldre informantene hadde et litt annet forhold til deltakelse i helseundersøkelser, i den forstand at de i større grad følte seg forpliktet til å delta. Denne plikten ble beskrevet i ordelag som minnet om en dugnad, hvor alle bidrar til et felles gode. Det kan ut fra dette se ut som de eldres motivasjon for deltakelse $\mathrm{i}$ helseundersøkelsen er preget av det som noen ganger kalles den "kommunitære borgerforståelse" (Hansen og Tjerbo 2003), at det nærmest ses som "god samfunnsånd" å delta i denne typen undersøkelser. Dette vil i så fall harmonere med mye samfunnsforskning som hevder at nordmenn har blitt mer individualistiske og at vi dermed er mindre preget av fellesskapsverdier enn tidligere (Hellevik 1996). Nå skal en som nevnt være forsiktig med å generalisere ut fra dette datamaterialet, men i den grad denne observasjonen stemmer er nok dette et trekk som er relativt spesielt for norske (eller i alle fall skandinaviske) forhold.

Når motivasjon og preferanser ser ut til å være forskjellig for de ulike gruppene i denne undersøkelsen, peker dette på et oversett område i frafallslitteraturen. Siden en studerer frafallsproblematikken isolert fra spørsmålet om hva som motiverer folk til å delta $i$ undersøkelser, er de strategiene for å redusere frafallet som beskrives i litteraturen stort sett "one size fits all"tilnærminger. Det tas i liten grad høyde for at motivasjon og preferanser varierer mellom undergrupper $i$ populasjonen.

Når vi i denne studien finner nettopp slike variasjoner, peker det på (minst) to viktige forhold som bør vurderes i planleggingen av undersøkelser: 1) Det er essensielt å gjøre grundig forarbeid for å forstå den populasjonen en ønsker å undersøke. Her vil det i noen tilfeller være nødvendig å gjøre egne forstudier av populasjonen. 2) Det bør benyttes flere informasjonsog rekrutteringsstrategier. Siden motivene er forskjellige må en både benytte flere argumenter og flere informasjonskanaler for å nå de ulike underkategoriene av målgruppen.

Resultatgjennomgang og diskusjon trekker frem flere forhold som vil være viktige for planleggingen av fremtidige helseundersøkelser: 
1) Praktiske grunner utgjør en betydelig årsaksfaktor til frafall. Strategisk bruk av påminnelser er en viktig strategi for å redusere denne typen frafall. Bruk av forhåndsvarsel har hittil ikke blitt vist å ha effekt for norske helseundersøkelser (jfr. Søgaard og Selmer 2005).

2) Problemer med å få fri fra jobb samt tap av lønn oppgis også som en praktisk barriere mot å delta i undersøkelsen. Mobile enheter som kan plasseres ved de største arbeidsplassene i fylket vil kunne redusere disse barrierene betraktelig. Dette vil også kunne være en viktig strategi for å nå "problemgruppen" yngre menn. Imidlertid krever dette betydelig samarbeid fra arbeidsgivere.

3) Incentiver bør brukes med forsiktighet, ettersom dette kan virke mot sin hensikt.

4) Informasjons- og motivasjonsarbeidet $i$ forkant av undersøkelsen bør gjøre bruk av flere argumenter og vise til både egennytte og forskningsmessig nytte. Også undersøkelsens lokale forankring bør vektlegges. Flere informasjonskanaler bør benyttes for å nå forskjellige grupper. I tillegg til informasjonsbrosjyrer og lignende, bør det benyttes flere informasjonskanaler for å nå forskjellige grupper. For en god oversikt over informasjonstiltak som kan benyttes i helseundersøkelser, se Kværnsveen (2002).

5) Informasjonsarbeidet bør vektlegge konfidensialitet og at datamaterialet ikke vil bli åpnet for noen form for kommersiell bruk.

6) Undersøkelsens koblinger til universitet og offentlige samarbeidspartnere bør synliggjøres i informa- sjonsarbeidet for å markere forskjellen mellom HUNT og kommersielle undersøkelser.

7) Informantene vektlegger at de ønsker rask tilbakemelding på resultatene. Rask tilbakemelding kan være med på å øke den opplevde egennytten av undersøkelsen.

\section{KONKLUSJON}

Denne studien har vist at motivene for deltakelse i helseundersøkelser kan være mangfoldige og sammensatte. Beslutningen om å delta i helseundersøkelser følger ikke alltid den bytteteoretiske logikken som mye av surveyforskningen legger til grunn. For enkelte respondentgrupper kan altruistiske motiver spille en like stor rolle som egennytten.

Når forskjellene i motiver også virker å være assosiert med utdanningsnivå og alder, vil dette kunne ha store implikasjoner for hvordan arrangører av undersøkelser legger opp sin rekrutterings- og informasjonsstrategi: Hvilke frafallsreduserende tiltak som fungerer vil være avhengig av hvilken populasjon undersøkelsen skal si noe om, og hvilken type undersøkelse det er snakk om.

Manglende kunnskap om dette kan i verste fall medføre systematiske skjevheter i datamaterialet. Bredere studier av de faktorene som ligger bak beslutninger om å delta/ikke delta bør derfor vies like stor oppmerksomhet som deskriptive frafallsanalyser dersom vi skal forstå frafallsproblematikken og finne mer effektive måter å bremse frafallsutviklingen på.

\section{REFERANSER}

Armstrong JS (1975). Monetary incentives in mail surveys. Public Opinion Quarterly 39 (1): 111-116.

Asch DA, Jedrziewski MK, Christakis NA (1997). Response rates to mail surveys published in medical journals. Journal of Clinical Epidemiology 50 (19): 1129-1136.

Belsby L (1997). Frafallsproblemet øker. Samfunnsspeilet 2: 10-13.

Belsby L, Vedø A (1998). Frafallsanalyse av helseundersøkelsen 1995. Notater 3/98, SSB, Oslo.

Brennan M, Hoek J (1992). The behaviour of respondents, nonrespondents, and refusers across mail surveys. Public Opinion Quarterly 56 (4): 530-535.

Caetano R (2001). Nonresponse in alcohol and drug surveys. Addiction 96 (11): 1541-1545.

Church AH (1993). Estimating the effect of incentives on mail survey response rates: a meta analysis. Public Opinion Quarterly 87 (1): 62-79.

DeLeeuw E, Hox J (1996). The effect of the interviewer on the decision to cooperate in a survey of the elderly. I: Laaksonen S (red.) International Perspectives on Nonresponse. Statistics Finland, Helsinki, pp 46-53.

DeMaio T (1980). Refusals: Who, where and why? Public Opinion Quarterly 44 (2): 223-233.

Dillman DA (2000). Mail and Internet Surveys. John Wiley \& Sons, New York.

Edwards P, Roberts I, Clarke M, DiGuiseppi C, Pratap S, Wentz R, Kwan I (2002). Increasing reponse rates to postal questionnaires: systematic review. British Medical Journal 324 (7347): 1183-1192.

Fox RJ, Crask MR, Kim J (1988). Mail survey response rates: A meta analysis of selected techniques for inducing response. Public Opinion Quarterly 52 (4): 467-491.

Goyder J (1987). The Silent Minority. Nonrespondents in Sample Surveys. Polity Press, Oxford.

Goyder J, Leiper J (1985). The decline in survey response: A social values interpretation. Sociology 19 (1): 55-71.

Groves RM, Dillman D, Eltinge JL, Little JAR (2002). Preface. I: Dillman D, Eltinge JL, Groves RM, Little JAR (red.) Survey Nonresponse. Wiley-Interscience, New York, pp 3-27. 
Hansen T, Tjerbo T (2003). Politisk engasjement, borgerroller og sosial kapital. Rapport 62, Makt- og demokratiutredningens rapportserie.

Haraldsen G (1999). Spørreskjemametodikk etter kokebokmetoden. Ad Notam Gyldendal, Oslo.

Harvey L (1987). Factors affecting response rates to mailed questionnaires: a comprehensive literature review. Journal of the Market Research Society 29 (3): 341-353.

Heberlein TA, Baumgartner R (1978). Factors affecting response rates to mailed questionnaires: A quantitative analysis of the published literature. American Sociological Review 43 (4): 447-462.

Hellevik O (1996). Nordmenn og det gode liv: Norsk monitor 1985-1995. Universitetsforlaget, Oslo.

Holmen J, Forsen L, Skjerve K, Gorseth M, Midthjell K, Oseland A (1989). Møter - møter ikke? Avdeling for helsetjenesteforskning, Rapport nr. 5/1989.

Jacobsen BK, Thelle DS (1988). The Tromsø Heart Study. Responders and nonresponders to a health questionnaire: do they differ? Scandinavian Journal of Social Medicine 16: 101-104.

Kalantar JS, Talley NJ (1999). The effects of lottery incentive and length of questionnaire on health survey response rates: A randomized study. Journal of Clinical Epidemiology 52 (11): 117-122.

Kværnsveen K (2002). Helseundersøkelsen i Oslo. Rapport om informasjonsarbeidet (http://www.fhi.no/tema/ helseundersokelse/oslo).

Linsky A (1975). Stimulating responses to mailed questionnaires. Public Opinion Quarterly 39 (1): 82-101.

Lund E, Gram IT (1998). Response rate according to title and length of questionnaire. Scandinavian Journal of Social Medicine 26 (2): 154-160.

Perneger TV, Etter JF, Rougemont A (1993). Randomized trial of use of a monetary incentive and a reminder card to increase the response rate to a mailed health survey. American Journal of Epidemiology 138 (9): 714-722.

Pietilä AM, Rantakallio P, Läärä E (1995). Background factors predicting nonresponse in a health survey of northern Finnish young men. Scandinavian Journal of Social Medicine 23 (2): 129-136.

Richiardi L, Boffetta P, Merletti F (2002). Analysis of nonresponse bias in a population-based case-control study on lung cancer. Journal of Clinical Epidemiology 55: 1033-1040.

Selmer R, Søgaard, AJ Bjertness E, Thelle D (2003). The Oslo Health Study: Reminding the non-responders effects on prevalence studies. Norsk Epidemiologi 13 (1): 89-94.

Sonne-Holm S, Sørensen TA, Jensen G, Schnohr P (1989). Influence of fatness, intelligence, education and sociodemographic factors on response rate in a health survey. Journal of Epidemiology and Community Health 43: 369-374.

SSB (1970). Helseundersøkelse 1968. Statistisk Sentralbyrå, Oslo.

SSB (1977). Helseundersøkelse 1965. Statistisk Sentralbyrå, Oslo.

SSB (1987). Helseundersøkelse 1985. Statistisk Sentralbyrå, Oslo.

SSB (1999). Helseundersøkelse 1995. Statistisk Sentralbyrå, Oslo.

Stinchcombe A, Jones C, Sheatsley P (1981). Nonresponse bias for attitude questions. Public Opinion Quarterly 45 (3): 359-375.

Søgaard AJ, Selmer R (2005). The Oslo Health Study (http://www.fhi.no/dav/6E0969CF5B.doc).

Søgaard AJ, Selmer R, Bjertness E, Thelle D (2004). The Oslo Health Study: The impact of self-selection in a large, population-based survey. International Journal for Equity in Health 3: 3.

Thomsen I, Siring E (1980). On the causes and effects of nonresponse. Norwegian experiences. Artikler fra Statistisk Sentralbyrå, nr. 121.

Tjerbo T, Kværner KJ, Botten G, Aasland OG (2005). Bruk av incentiver for å øke svarandelen i spørreskjemaundersøkelser. Tidsskrift for den Norske Lageforening 125 (18): 2496-2497.

Watruba TR (1966). Monetary incentives and mail questionnaire response. Journal of Marketing 3: 398-400. 